\title{
A rare manifestation of burns after lightning strike in rural Ghana: a case report
}

\author{
Paschal Awingura Apanga*, John Atigiba Azumah and Joseph Bayewala Yiranbon
}

\begin{abstract}
Background: Lightning is a natural phenomenon that mostly affects countries in the tropical and subtropical regions of the globe, including Ghana. Lightning strikes pose a global public health issue. Although strikes to humans are uncommon, it is associated with high morbidity and mortality.
\end{abstract}

Case presentation: We present a case of a 10-year-old Ghanaian girl who got second-degree burns after being struck by lightning. She was put on an intravenous broad-spectrum antibiotic (ceftriaxone), Ringer's lactate, and her burns were dressed with sterile gauze impregnated with Vaseline (petroleum jelly) and silver sulfadiazine ointment. There was marked improvement on the $16^{\text {th }}$ day of treatment despite the lack in capacity of the hospital to carry out some laboratory diagnostic tests. On the $21^{\text {st }}$ day of treatment, the burns were completely healed without scars and contractures.

Conclusions: This is evidence of burns due to lightning strike, despite its rare occurrence. This report will help inform those in doubt, particularly in communities where lightning injuries are associated with widespread superstition. The case report also revealed how rural healthcare can be challenging amid a lack of basic diagnostic equipment and logistics. However, in resource-limited settings, Vaseline (petroleum jelly) and silver sulfadiazine could be used in the treatment of burns.

Keywords: Burns, Lightning, Rare, Vaseline, Silver sulfadiazine

\section{Background}

Lightning is discharge of electrical current as a result of an imbalance between the electrical charge of the clouds and the Earth's surface [1]. It is a powerful and spectacular natural phenomenon, and usually occurs when there is a difference in voltage of $30,000 \mathrm{~V}$ or higher, which exceeds the inherent resistance $[1,2]$. Usually thunder, a sound produced by lightning, follows it after it strikes the Earth's surface. Lightning is a global public health issue and is the second leading cause of weather-related deaths [3, 4]. It accounts for about 24,000 deaths and 240,000 injuries annually [5].

Lightning mostly occurs during summer and, in countries like Ghana, it occurs during the rainy season $[6,7]$. It strikes the Earth's surface more than eight million times a day [1]. Lightning-related injuries are more

\footnotetext{
* Correspondence: awingura@yahoo.com

Talensi District Hospital, Ghana Health Service, Upper East Region, Tongo, Ghana
}

common in the young, with a vulnerable age group of 10-29 years [8]. Males have a five times greater risk of being struck by lightning than their female counterparts [9]. Lightning usually occurs during outdoor activities rather than indoors. Individuals engaging in outdoor activities such as fishing golfing, camping, swimming, boating, hiking, and so on, are more prone to strikes by lightning $[1,10]$. However, indoor strikes by lightning have also been reported [9]. The risk of being struck by lightning is dependent, therefore, on seasonal, regional, and temporal factors [3].

Lightning injuries are uncommon in humans, although long-term morbidity and high mortality has been reported [7]. Lightning strikes can cause ear damage, brain damage, cardiac failure, blunt trauma, neurological syndromes, muscle injuries, eye injuries, skin lesions, and burns [1]. Unlike other high-voltage-related accidents, lightning injuries do not only involve high-voltage electricity, but they can also occur with a very short 
exposure time to the electric current. Hence, lightning injuries are not only as a result of the electric current, but may be due to high temperatures and blast waves $[11,12]$. Lightning injuries can affect the human body through various mechanisms. It may affect the body by direct strike, side splash, contact, blunt trauma, ground current, and injury by a weak upward streamer [13]. We report the first case of a patient with burns from lightning strike in rural Ghana who reported to a hospital for treatment.

\section{Case presentation}

A 10-year-old Ghanaian girl presented to a hospital with burns on her right arm, abdomen and both thighs after she was struck by lightning during a downpour. She was struck by lightning when she opened her bedroom door to walk out. On general examination, she weighed $25 \mathrm{~kg}$ and was febrile with a temperature of $38.0{ }^{\circ} \mathrm{C}$, not pale, not dehydrated, and not jaundiced. Her blood pressure $(100 / 70 \mathrm{mmHg})$, pulse ( 80 beats per minute) and respiratory rates (16 cycles per minute) were normal. She sustained second-degree burns on the posterior part of her right arm, abdomen, anterolateral part of her right thigh and the anteromedial part of her left thigh as shown in Fig. 1. Using the "rule of nines" for estimating the total body surface area for burns of persons at least 10 years old [14], the estimated burnt surface area was $9 \%$. The affected areas of the burns were erythematous with blisters. However, examinations of her gastrointestinal, cardiovascular, and neurological systems were all normal.

Our patient was admitted to the children's ward and initial laboratory results showed leukocytosis of $15 \times$

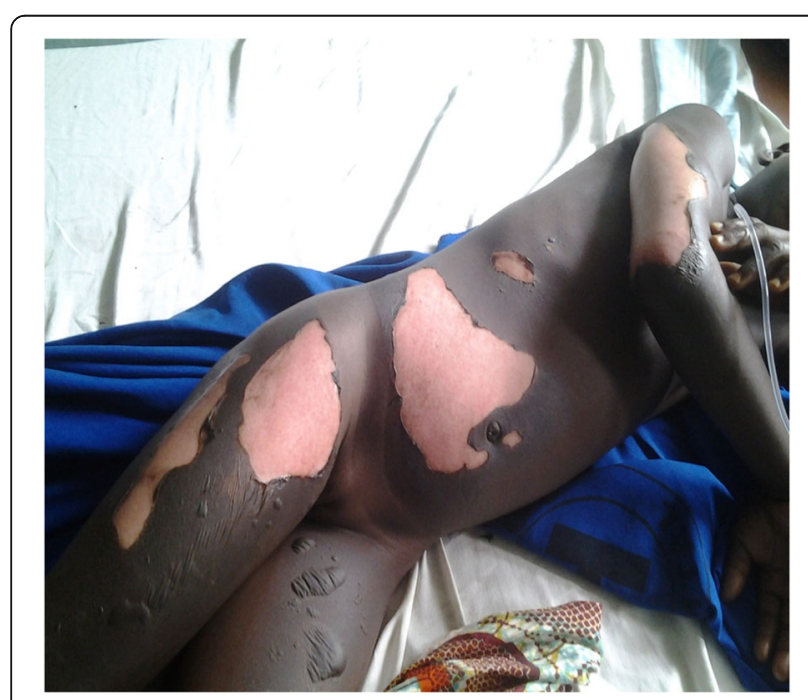

Fig. 1 Image showing burns from lightning strike on the first day of presentation
$10^{9 /} \mathrm{L}$ with neutrophilia of $80 \%$. Serum urea $(4 \mathrm{mmol} / \mathrm{L})$, creatinine $(80 \mu \mathrm{mol} / \mathrm{L})$, sodium $(138 \mathrm{mmol} / \mathrm{L})$, and potassium $(4.1 \mathrm{mmol} / \mathrm{L})$ levels were normal. A routine urine test was normal. However, the hospital lacked the capacity to carry out wound swabs and blood tests for culture and sensitivity. She was put on an intravenous broad-spectrum antibiotic (ceftriaxone $1 \mathrm{~g}$ daily) for 7 days and oral paracetamol $500 \mathrm{mg}$ every 8 hours for 5 days. She was also given $25 \mathrm{mg}$ diclofenac every 8 hours for 5 days to relieve pain. A urethral catheter was inserted to monitor her urine output while she was given $900 \mathrm{~mL}$ of Ringer's lactate intravenously for the first 24 hours to ensure that she remained hemodynamically stable. Half of the volume of fluid $(450 \mathrm{~mL})$ was administered in the first 8 hours and the remainder was given in the next 16 hours. The burns were dressed daily with sterile gauze impregnated with Vaseline (petroleum jelly) and silver sulfadiazine. In addition, our patient was covered with a blanket to prevent hypothermia. Our patient had physiotherapy daily to prevent contractures of her affected limbs.

After 48 hours of treatment, her temperature became normal. Treatment was continued and her vital signs were checked regularly and remained normal. On the $16^{\text {th }}$ day of treatment in the ward, the burns had almost completely healed and there were no contractures as shown in Fig. 2. The full blood count was repeated and it was found to be normal. Our patient was discharged from the ward and put on oral amoxicillin $500 \mathrm{mg}$ every 8 hours for 5 days. She and her guardian were asked to return to the hospital daily for dressing as their residence was close to the hospital. On the $21^{\text {st }}$ day of treatment, the burns were completely healed and treatment was discontinued.

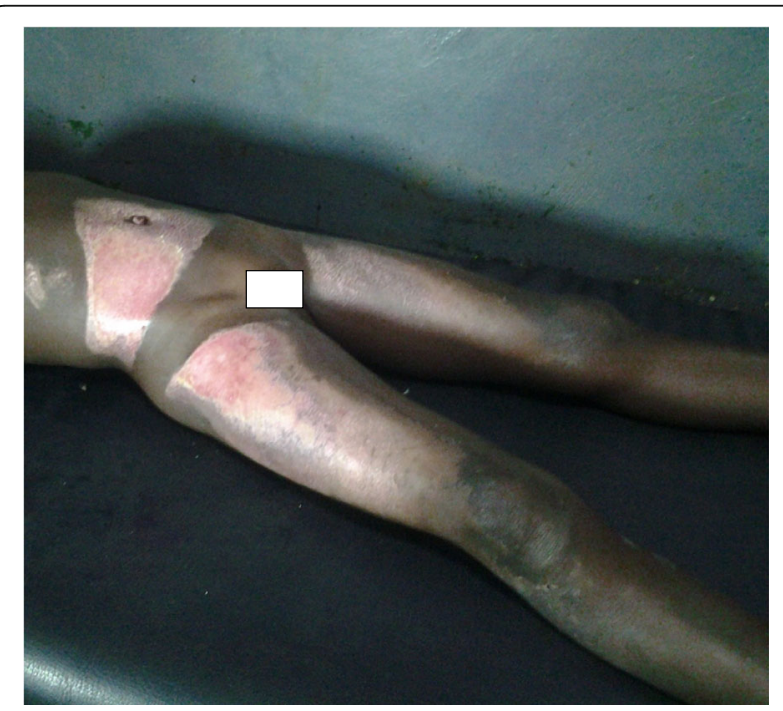

Fig. 2 Image on the $16^{\text {th }}$ day of treatment showing the healing of burns 


\section{Discussion}

This case report is unusual as the incidence of burns as a result of lightning strike is rare in Ghana. Most cases of burns reported are mainly due to fires, chemicals, electricity, and hot liquids $[15,16]$. In many sub-Saharan African countries, including Ghana, lightning injuries have largely been blamed on various misconceptions including religious beliefs and superstitions, and afflicted individuals may face social stigma $[4,17,18]$. However, this is misleading as lightning injuries have been well documented scientifically [1].

The lightning injury in this study occurred when our patient tried to step out of her bedroom. This finding is contrary to many studies that reported lightning strikes during outdoor activities [1, 10, 19, 20]. However, our finding was consistent with studies by Mistovich et al., who reported lightning strikes that occurred indoors [9]. Opening of doors when indoors has been found to be a risk factor for lightning injuries [9], this might have accounted for the lightning strike in this study.

The fever, high white blood cell count, and leukocytosis from the initial laboratory results were suggestive of a bacterial infection. However, the hospital lacked the capacity to carry out wound swabs and blood tests for culture and sensitivity, which might have informed clinicians of the focus of infection and the type of bacterial organism involved. The lack of diagnostic logistics and equipment reemphasizes the challenges clinicians encounter in providing primary healthcare in poorly resourced settings [21]. In spite of the challenges encountered by the clinicians, the parenteral administration of ceftriaxone as well as the gauze dressing impregnated with Vaseline and silver sulfadiazine seems to have brought the fever, high white blood cell, and leukocytosis under control to normal levels. The use of sterile gauze dressing impregnated with Vaseline and silver sulfadiazine was successful in treating the burns. Similar studies have found silver sulfadiazine to be effective in the treatment of burns [22]. On the contrary, some studies have reported hypersensitivity reactions, wound contracture, and scar formation associated with the usage of silver sulfadiazine in the treatment of burns $[14,23]$. This was not found in our study and might probably be due to the addition of Vaseline to silver sulfadiazine during the gauze dressings.

\section{Conclusions}

This report has provided evidence of a case of a patient with burns resulting from lightning strike, despite its rare occurrence. This also serves as evidence for those in doubt, particularly in communities where lightning injuries are associated with widespread superstition. The case report also revealed how challenging providing primary care in poorly resourced settings can be amid lack of basic diagnostic equipment and logistics. However, we recommend that in resource-limited settings, Vaseline (petroleum jelly) and silver sulfadiazine can be used in the treatment of burns.

\section{Acknowledgements \\ We wish to thank our patient and her family for their support and cooperation during the study.}

\section{Funding}

None.

\section{Availability of data and materials}

Not applicable.

\section{Authors' contributions}

PAA conceived the study. PAA, JAA, and JBY managed the patient. PAA and JBY wrote the first draft. JAA critically revised the manuscript. All authors read and approved the final manuscript.

Ethics approval and consent to participate

Not applicable.

\section{Consent for publication}

Written informed consent was obtained from the patient's legal guardian for publication of this case report and any accompanying images. A copy of this consent is available for review by the Editor-in-Chief of this journal.

\section{Competing interests}

The authors declare that they have no competing interests.

\section{Publisher's Note}

Springer Nature remains neutral with regard to jurisdictional claims in published maps and institutional affiliations.

Received: 16 April 2017 Accepted: 2 July 2017

Published online: 25 July 2017

\section{References}

1. Pfortmueller CA, Yikun Y, Haberkern M, Zimmermann EH, Exadaktylos AK. Injuries, sequelae, and treatment of lightning-induced injuries: 10 years of experience at a Swiss Trauma Center. Emerg Med Int. 2012;2012:167698. doi:10.1155/2012/167698.

2. Cooray V, Cooray C, Andrews CJ. Lightning caused injuries in humans. J Electrost. 2007;65(5-6):386-94.

3. Ritenour AE, Morton MJ, McManus JG, Barillo DJ, Cancio LC. Lightning injury: a review. Burns. 2008;34(5):585-94.

4. Biswas A, Dalal K, Hossain J, Baset KU, Rahman F, Rahman Mashreky S. Lightning Injury is a disaster in Bangladesh? - Exploring its magnitude and public health needs. F1000Res. 2016;5:2931. doi:10.12688/f1000research.9537.1.

5. Walsh KM, Cooper MA, Holle R, Rakov VA, Roeder WP, Ryan M. National Athletic Trainers' Association position statement: lightning safety for athletics and recreation. J Athl Train. 2013;48(2):258-70. doi:10.4085/10626050-48.2.25.

6. Sumangala CN, Kumar MP. Lightning death: a case report. J Indian Acad Forensic Med. 2015;37(1):93-5.

7. Holle RL. A Summary of Recent National-Scale Lightning Fatality Studies. Wea Climate Soc. 2016;8:35-42.

8. Forster SA, Silva IM, Ramos ML, et al. Lightning burn-review and case report. Burns. 2013;39(2):e8-12.

9. Mistovich JJ, Krost WS, Limmer DD. Beyond the basics: lightning-strike injuries. EMS Mag. 2008;37(3):82-9.

10. Modayil PC, Lloyd GW, Mallik A, Bowdler DA. Inner ear damage following electric current and lightning injury: a literature review. Eur Arch Otorhinolaryngol. 2014;271(5):855-61.

11. Lederer WKG. Notfallmedizinische Versorgung von Blitzund Stromschlagverletzungen. Anaesthesist. 2005;51(11):1120-9.

12. Slesinger TL, Bank M, Drumheller BC, et al. Immediate cardiac arrest and subsequent development of cardiogenic shock caused by lightning strike. J Trauma. 2010;68(1):E5-7. 
13. Fred Z. Blitzunfall-Energie"ubertragungsmechanismen undmedizinische Folgen. Dtsch Arztebl. 2007;104(51-52):3545-9.

14. Hyland EJ, Connolly SM, Fox JA, Harvey JG. Minor burn management: potions and lotions. Aust Prescr. 2015;38(4):124-7. doi:10.18773/austprescr. 2015.041.

15. Agbenorku P. Burns functional disabilities among burn survivors: a study in Komfo Anokye Teaching Hospital, Ghana. Int J Burns Trauma. 2013;3(2):78-86.

16. Agbenorku P, Agbenorku M, Fiifi-Yankson PK. Pediatric burns mortality risk factors in a developing country's tertiary burns intensive care unit. Int J Burns Trauma. 2013;3(3):151-8.

17. Trengove E, Jandrell I. Lightning myths in southern Africa. Nat Hazards. 2015;77(1):101-10.

18. Ikpeme IA, Udosen AM, Asuquo ME, et al. Lightning burns and traditional medical treatment: a case report. West Afr J Med. 2007;26(1):53-4.

19. Nguyen B, MacKay M, Bailey B, Klassen T. Epidemiology of electrical and lightning related deaths and injuries among Canadian children and youth. Inj Prev. 2004;10(2):122-4. doi:10.1136/ip.2003.004911.

20. Bhargava AN, Kasundra GM, Khichar S, Bhushan BSK. Lightning strikeinduced brachial plexopathy. J Neurosci Rural Pract. 2014;5(4):399-400. doi:10.4103/0976-3147.140000.

21. Apanga PA, Awoonor-Williams JK, Acheampong M, Adam MA. A presumptive case of human rabies: a rare survived case in rural Ghana. Front Public Health. 2016;4:256. doi:10.3389/fpubh.2016.00256.

22. Chu CY, Peng FC, Chiu YF, et al. Nanohybrids of silver particles immobilized on silicate platelet for infected wound healing. PLoS One. 2012;7(6):e38360. doi:10.1371/journal.pone.0038360.

23. Saeidinia A, Keihanian F, Lashkari AP, et al. Partial-thickness burn wounds healing by topical treatment: A randomized controlled comparison between silver sulfadiazine and centiderm. Medicine. 2017;96(9):e6168. doi:10.1097/MD.0000000000006168

\section{Submit your next manuscript to BioMed Central and we will help you at every step:}

- We accept pre-submission inquiries

- Our selector tool helps you to find the most relevant journal

- We provide round the clock customer support

- Convenient online submission

- Thorough peer review

- Inclusion in PubMed and all major indexing services

- Maximum visibility for your research

Submit your manuscript at www.biomedcentral.com/submit

) Biomed Central 